\title{
THEORETICAL PERSPECTIVE OF LEVEL A2 OF THE ENGLISH LANGUAGE
}

\author{
PERSPECTIVA TEÓRICA DEL NIVEL A2 DEL IDIOMA INGLÉS
}

Recibido: 31 de octubre de 2021

Aceptado: 01 de diciembre de 2021
I.A. Álvarez Portales ${ }^{1}$

E.A. Pesina Roldán ${ }^{2}$

J. I. Martínez Corona ${ }^{3}$

\section{RESUMEN}

Este artículo presenta los resultados de un proceso cualitativo con alcance descriptivo que comprende un análisis documental, que tuvo como objetivo generar una perspectiva sobre el nivel A2 de inglés del Marco Común Europeo de Referencia para las Lenguas, como un esfuerzo por describir sus propiedades o dimensiones que nos permitan tener elementos referenciales claros. Para cumplir con este objetivo, se determinaron tres categorías de análisis: caracterización del nivel A2, habilidades de inglés en el nivel A2 y posibles certificaciones. Como conclusión general del estudio, se afirma que fue posible generar la perspectiva teórica que se pretendía con respecto al nivel y dar a conocer su físonomía; así como las capacidades, habilidades y posibilidades de una persona que demuestre esta destreza, la cual proporciona una base para futuras decisiones o proyectos.

PALABRAS CLAVE: Inglés, Análisis Documental, MCERL, A2, Idiomas.

\section{ABSTRACT}

This paper presents the results of a qualitative process with a descriptive scope comprising a documentary analysis, that aimed to generate a perspective on the A2 level of English of the Common European Framework of Reference for Languages, as an effort to describe its properties or dimensions that allow us to have clear referential elements. In order to meet this objective, three categories of analysis were determined: characterization of level A2, English skills at level A2, and possible certifications. As a general conclusion of the study, it is affirmed that it was possible to generate the theoretical perspective that was intended with regard to the level and to make known its physiognomy; as well as the capacities, abilities and possibilities of a person who demonstrates this skill, which provides a basis for future decisions or projects.

KEY WORDS: English, Documentary Analysis, CEFRL, A2, Languages.

\section{INTRODUCTION}

Over time, the English language has become a fundamental language for communication in a globalized world, which is essential for interaction between the different countries of the world. In this sense, it takes importance the information that provides Latorre (2016), who expresses that about 375 million people have English as their native language; however, another equal number have it officially as their second language. Now, regarding the first group, where the English language is dominant, it stands out that they live in countries such as the United States, the United Kingdom, Canada, Australia, New Zealand and Ireland; Then, for to the second group, they have their origin in Hong Kong, Singapore, Nigeria, the Philippines, Malaysia and India, here English is used in a preponderant way as a means of global communication between population groups.

The latter is considered highly relevant, considering the context of the opening of borders, as

\footnotetext{
${ }^{1}$ Operational Director Univer Global Language, San Luis Potosi, ilse_portales@ @otmail.com

${ }^{2}$ Coordinator Central - Middle Zone COBACH, San Luis Potosi, eliaspesinaroldan@ hotmail.com

${ }^{3}$ Professor at the Tecnológico Nacional de México, Campus San Luis Potosí, jose.mc@slp.tecnm.mx
} 
well as international agreements and treaties. Here the English language becomes a bridge of communication between countries to promote economic, cultural, educational, commercial and monetary relations, with the benefits that this entails.

Now, if the focus is on personal life, English language learning represents a window of opportunity, especially in the professional sphere. These situations and contexts mean that

English is the most widely taught language in the world; in this sense, it is common to refer to the foreign language teaching program as being equivalent to English language teaching. This is directly related to the fact that English is a language that is taught in more than 100 countries, among which the following stand out for their global importance: China, Germany, Russia, Spain, Egypt and Brazil. Specifically, in the European Union (EU), the teaching of English is required from the primary education stage. Upon further analysis, in the EU, 73\% of primary school students are learning English; at the secondary level this percentage exceeds 90\%; and in the pre-professional and professional stage it reaches $74.9 \%$ of its students (Chávez-Zambano, 2017).

In relation to the foregoing, situating ourselves in what happens in Mexico, it is relevant the information provided by the Mexican Institute for Competitiveness (IMCO), which indicates that only $5 \%$ of the population speaks or understands English (Becerril, 2015). This data is highly relevant, due to the importance of language as an indispensable factor for the competitiveness of people, organizations and countries. Therefore, this situation becomes indispensable for the knowledge of the language to begin to be acquired by the population; this, due to the global demand and especially for the needs of global companies to meet their communication processes, their ability to do business and even develop conversations to close agreements.

All these elements favor and are the ones that support greater competitiveness and economic spillover; therefore, Mexicans find in the English language a pending task. This situation is aggravated when considering that of the people who understand the language in Mexico, only $14 \%$ do so at an advanced level; the remaining $86 \%$ have an intermediate or lower level of proficiency. However, this is not enough, since the working world is becoming more and more competitive due to the direct relationship between high competitiveness and English proficiency. Therefore, this requirement has become a decisive factor in the offer and sustainability of jobs (Entrepeneur, 2018). and highlights that, in global companies located in Mexico, a little more than three quarters of the number of people who have lost their jobs in positions with a high level of responsibility, is because they do not know English (Chávez, 2020).

In another order of ideas, to know the mastery level of the English language, typically, it is done through a certification exam, which is designed and applied by an organization with recognition and prestige in the language, mainly by the English-speaking governments. In this sense, there are several companies in the market, known as certifiers in the language, which establish the standards to determine the levels of language proficiency. In this sense, the British Council state that the Common European Framework of Reference for Languages (CEFR) is the system that not only defines, but also explains the levels of expression and comprehension for languages such as English. For which it sets, as linguistic competences: oral expression, written expression, linguistic comprehension and oral comprehension.

This standard is mainly used in Europe; however, there are a number of countries for which it is also used as a reference. It is very useful for institutions and teachers, as it allows them 
to assess the language skills described above (British Council, 2021). It is important to mention that, as marked by the CEFRL, this standard comprises three blocks (Figure 1): basic level, denoted by the letter A; independent level, which is related to $\mathrm{B}$; and proficient level or C. These levels, in turn, are divided into two sub-levels 1 and 2.

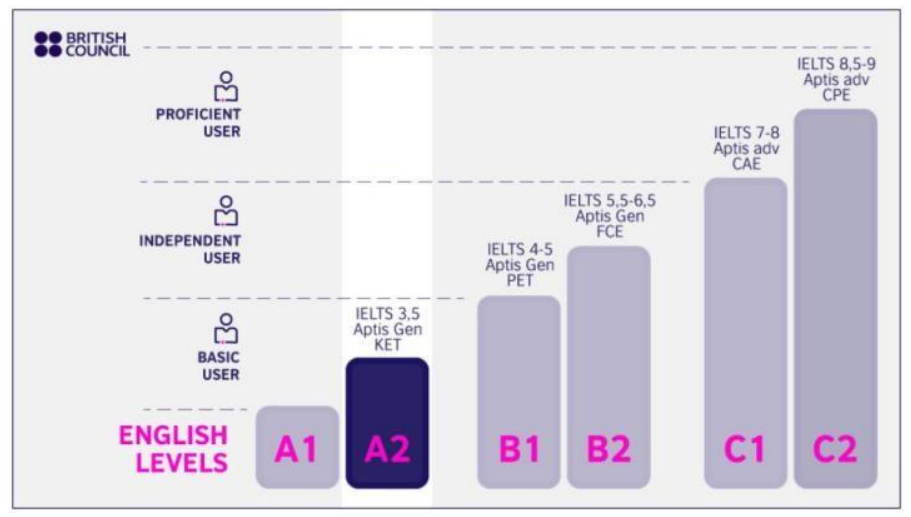

Figure 1. English Language Levels (British Council, 2021)

Related to the above, it is observed that, in various educational institutions in Mexico, the A2 level is designated as a requirement for the degree and obtaining a degree in various academic programs. This is considered relevant; therefore, in this paper we report a documentary analysis, based on a literature review, in order to generate a theoretical perspective of the subject and to know, among other things, the physiognomy of the level, the capabilities, skills and possibilities that are demonstrated by having this level.

It is worth mentioning that this work is of a qualitative nature, during this first stage the theoretical processes will be reviewed, as well as the different accreditations of the English language and the most recognized certifying houses worldwide.

Equivalences with each of the existing certifications, such as Cambridge, TOEFL, TOEIC, IELT, TOEIC, IELTS, etc., are also reviewed.

In a later process, a field work will be carried out through questionnaires and a statistical analysis with students, A2 level applicants and certifiers that will guarantee the certainty and accuracy of the methodology to be used to accredit the A2 level.

It is worth mentioning that this work is a qualitative nature, during this first stage the theoretical processes will be reviewed, as well as the different accreditations of the English language and the most recognized certifying houses worldwide. Equivalences with each of the existing certifications, such as Cambridge, TOEFL, TOEIC, IELT, TOEIC, IELTS, among other, are also reviewed.

The results of this work will support a subsequent research process that allows to grant certainty and precision of a methodology to evaluate and accredit the level of A2 mastery of the English language. Therefore, this qualitative study with a descriptive scope will be useful for an instrumental quantitative study.

\section{METHODOLOGY}

This work is the result of a research with a qualitative approach, which according to Grajales (2000) this approach is used for studies with a holistic effort that is oriented to describe the qualities of a phenomenon or subject of study. The objective was to generate a theoretical 
perspective on the A2 level of English of the Common European Framework of Reference for Languages, which involves exposing and analyzing various elements related to theories, conceptualizations and background (Hernández et al., 2014) on the subject, this to have a clear view on the proposed approach and have a basis for future work.

The study was proposed under a descriptive scope according to what is recommended by Hernández et al. (2014) this type of study is useful when it is necessary to specify properties; as well as the properties or profiles of the unit of analysis, in this case, documentary. For the development of the study, the following methodological procedure was followed (CIFE, 2016):

1. Understand and categorize the variables or dimensions of the object of study.

2. Determine the context of searches using keywords.

3. Search for articles, books, manuals, and generally relevant materials.

4. Extract the information, analyses it, contrast it to extract the relevant information.

\section{RESULTS}

\section{Characterization of Level A2}

The English language proficiency level, known as A2, is the second element of the classification or definition of language levels proposed by the Council of Europe according to the Common European Framework of Reference for Languages (CEFR). In its scope it is described as a basic level of proficiency; by means of which, a person can communicate with basic concepts and can express basic needs. From this level onwards, a person is considered to be functional for communication and has basic competences useful for obtaining information about courses, scholarships and basic employment situations.

To be considered A2 proficient in English, a person must demonstrate a range of language skills. That is, a person must be able to understand language in personal, family and work contexts, with basic performance; demonstrate proficiency in structuring clear but slow speech; and understand short, simple texts on familiar topics.

Continuing with the above, it is expressed that an A2 level of English should be sufficient to carry out tourist activities in an English-speaking country, as well as to socialize with English-speaking people. However, it is important to clarify that, in order to develop friendships in greater depth, an A2 level would not be sufficient. Now, what it does allow is to establish communication with English-speaking colleagues, but in a limited way. As for academic subjects, this level would not allow to successfully develop official studies or to efficiently understand materials and media in scientific journals.

To complete this reasoning, the competences of a person with an A2 level of English, according to the CEFR, are shown below:

- A person is able to understand sentences and expressions for frequent use in contexts of immediate relevance such as personal, family, shopping, employment, all in a basic way.

- Can communicate in simple, straightforward and routine tasks requiring a basic exchange of information on mainly familiar and routine matters.

- Also, you can describe in simple and straightforward terms aspects of your personal experience, immediate environment and issues in areas of immediate need.

Now, referring to the mechanism to know the level of mastery, it is considered that the most 
convenient method is to apply a standardized test with the characteristic that it is of high quality. Among the main ones, the following can be mentioned (Table 1):

Table 1. Main Standardized Tests for Level A2 (English First Set, 2021)

\begin{tabular}{|l|l|}
\multicolumn{1}{|c|}{ Test } & \multicolumn{1}{c|}{ Score equivalent to A2 level $^{\mathbf{1}}$} \\
\hline Oxford Test of English & 66 \\
\hline IELTS & Level 4 \\
\hline TOEIC (R\&L) Total & $225-545$ \\
\hline Cambridge English Scale & $120-139$ \\
\hline TOEFL IBT & $\mathrm{n} / \mathrm{a}$ \\
\hline Global English Scale (Pearson) & Level 4 \\
\hline
\end{tabular}

\section{A2 level English skills}

On this context, the association EF English First (2021), a company of a worldwide nature and importance used as a reference in the world in the teaching of this language due to its presence in more than fifty countries, mentions on its official website that the official "can do" statements are divided into smaller parts for didactic purposes. This more detailed breakdown of skills can help to independently assess the level of English or help a teacher to evaluate the level of a student.

Among its reference points, it indicates as a person with A2 level skills a person who can use the scope of an A1 level benchmark and additionally is also able to:

- Evaluate the performance of co-workers in the workplace.

- Relate events from the past, including weekend activities and interesting stories.

- Describe past life, giving details about important milestones.

- Entertain someone at home or visit a friend or colleague at their home.

- Discuss vacation plans and then tell friends and colleagues about this experience.

- Talk about the natural world and travel to see animals and natural areas in their country.

- Talk about movies they like and choose a movie to watch with their friends.

- Discuss clothes and the type of clothes people like to wear.

- Participate in basic communication at work, including attending meetings on family issues.

- Describe an accident or injury, get medical help from a doctor, and get a prescription for medicine.

- Participate in basic business social activities, welcome guests and attend networking events.

- Understand and make basic business proposals in area of expertise.

- Talk about and explain the rules of the games.

It also specifies that, although progress will depend on the type of course and the individual student, students can expect to reach A2 level in English with two hundred hours of exposure of the language.

\section{Certifications}

\section{KET/KETfS}

In the case of certifications, Cambridge is one of the world's most prestigious worldwide (Cambridge Assessment English, 2021). It is based on the evaluations of the University of 
Cambridge, particularly Cambridge Assessment English. Its exams were developed in 1967 and they mention that the Cambridge English: A2 Key, also known as Key English Test (KET), is the lowest level general English exam in the Cambridge English range which demonstrates the speaker's competence to communicate in basic English in everyday situations.

Cambridge English: A2 Key for Schools (KETfS) is at the same level as Cambridge English: A2 Key and leads to exactly the same internationally accepted certificate; however, it emphasizes as the only difference the content of the exam, since it is aimed at the interests and experiences of schoolchildren. It also mentions that it is of utmost importance to have had at least 250 hours of exposure to study or practice and to validate ability to speak, write and understand basic English. This test is the first step in developing English language skills for future work or study.

To take the test, it is needed to ask and answer questions about yourself and others, understand announcements and instructions when people speak slowly and clearly, and tell people what is thought about something. Table 2 shows the certification test specifications.

Within its description, it specifies that this exam consists of three parts. As the first and second of them, explains that the reading, writing and listening comprehension exams are taken on the same day. Subsequently a new appointment is developed for the application of the oral evaluation.

Table 2. Certification Assessment Specifications (Cambridge Assessment English, 2021)

\begin{tabular}{|l|l|l|l|}
\hline KET / KETFS & $\begin{array}{c}\text { Reading and } \\
\text { Writing }\end{array}$ & Listen to & Speak \\
\hline Time allowed & 1 hour 10 minutes & 30 minutes & $\begin{array}{c}8-10 \text { minutes per } \\
\text { pair of candidates }\end{array}$ \\
\hline Brands (\% of total) & $50 \%$ & $25 \%$ & $25 \%$ \\
\hline
\end{tabular}

TOEIC

Prospectively, in Mexico, the TOEIC (Test of English for International Communication) (ETS TOEIC, 2021) since 1979 is the most widely used test, with more than 7 million tests taken and with worldwide recognition. It is a standardized test of English for companies, educational institutions and individuals is performed continuously, indistinctly. For the business environment, the main purposes are: recruitment, promotion and training of staff and their candidates; with regard to the educational level, it is used to place at an appropriate level and in accordance with the capabilities and personal skills of the student; finally, individually it is intended to receive accreditation and apply for new positions or job promotions.

Within its structure there are two tests, one of them evaluates the receptive skills of English (reading and listening comprehension) and the other evaluates the productive skills (oral and written). Depending on the profile of the person who wishes to take the test, he/she can choose to take both tests or just one, according to his/her needs. The structure of each of the tests is different, as well as their scores. There are a variety of methods of preparation for the TOEIC, from self-study to courses and practice tests that will contribute to the accreditation 
of this.

As for the TOEIC, can be mentioned that the reading and listening comprehension test is the most popular of the two tests and it is taken in specialized centers or educational institutions that have a certificate that accredits them as evaluators. Its score ranges from 10 to 990 points. In addition, it is important to note that the reading and listening comprehension skills are weighted equally.

The oral and written exam is computer-based, so this version does not involve an evaluator; rather, the student records and writes his or her answers as appropriate to the section of the exam. As with the previous exam, the oral and written components are weighted equally. The final score for this exam ranges from 0 to 400 points.

It is important to mention that at each level of certification, A1, A2, B1, B2, C1, C2, a minimum number of points is required for each skill. In the case of A2 (Table 3), the following score is required to pass the exam:

Table 3. Minimum scores for Level A2 (English First Set, 2021)

\begin{tabular}{|c|c|c|c|}
\hline MCERL & Listening and Reading & Writing & Speaking \\
\hline A2 & $225-545$ & 70 & 90 \\
\hline
\end{tabular}

IELTS

The International English Language Testing System (IELTS) is a test that has more than 10,000 organizations worldwide that are recognized and approved by the IELTS (IELTS, 2021). Your ability to listen, read, write and speak English will be assessed during a test. The IELTS is scored on a scale of 1 to 9 and Table 4 shows the skill name and description of the skill in consideration of the score obtained.

Table 4. Description of the table (IELTS, 2021)

\begin{tabular}{|c|l|l|}
\hline Score & \multicolumn{1}{|c|}{ Skill level } & \multicolumn{1}{|c|}{ Description } \\
\hline 9 & Expert User & $\begin{array}{l}\text { The examinee has a fully operational command of the } \\
\text { language. His or her use of English is appropriate, } \\
\text { accurate, and fluent, and shows a thorough understanding. }\end{array}$ \\
\hline 8 & Very good user & $\begin{array}{l}\text { The examinee has a fully operational command of the } \\
\text { language with occasional unsystematic inaccuracies and } \\
\text { inappropriate usage. They may misunderstand some things } \\
\text { in unfamiliar situations. They handle complex and detailed } \\
\text { argumentation well. }\end{array}$ \\
\hline 7 & Good user & $\begin{array}{l}\text { The examinee has a working command of the language, } \\
\text { although with occasional inaccuracies, inappropriateusage } \\
\text { and misunderstandings in some situations. They generally } \\
\text { handle complex language well and understand detailed } \\
\text { reasoning. }\end{array}$ \\
\hline
\end{tabular}




\begin{tabular}{|c|l|l|}
\hline Score & \multicolumn{1}{|c|}{ Skill level } & \multicolumn{1}{|c|}{ Description } \\
\hline 6 & Competent User & $\begin{array}{l}\text { The examinee has an effective command of language } \\
\text { despite some inaccuracies, inappropriate use, and } \\
\text { misunderstandings. They can use and understand fairly } \\
\text { complex language, especially in familiar situations. }\end{array}$ \\
\hline 5 & Modest user & $\begin{array}{l}\text { The test taker has a partial command of the language and } \\
\text { adapts to the general meaning in most situations, although } \\
\text { he/she is likely to make many mistakes. They should be } \\
\text { able to handle basic communication in their own field. }\end{array}$ \\
\hline 4 & Limited user & $\begin{array}{l}\text { The examinee's basic competence is limited to familiar } \\
\text { situations. They often show comprehension and } \\
\text { expression problems. They cannot use complex language. }\end{array}$ \\
\hline 3 & Extremely limited user & $\begin{array}{l}\text { The examinee conveys and understands only general } \\
\text { meaning in very familiar situations. There are frequent } \\
\text { interuptions in communication. }\end{array}$ \\
\hline 1 & Intermittent user & $\begin{array}{l}\text { The test taker has great difficulty understanding spoken } \\
\text { and written English. }\end{array}$ \\
\hline & $\begin{array}{l}\text { The examinee does not have the ability to use the } \\
\text { language, except for a few isolated words. }\end{array}$ \\
\hline
\end{tabular}

To put this into clearer context, the IELTS equivalent level to validate a person as level A1 (CEFR scale) is 4 . Below is Figure 2 of the CEFR equivalency.

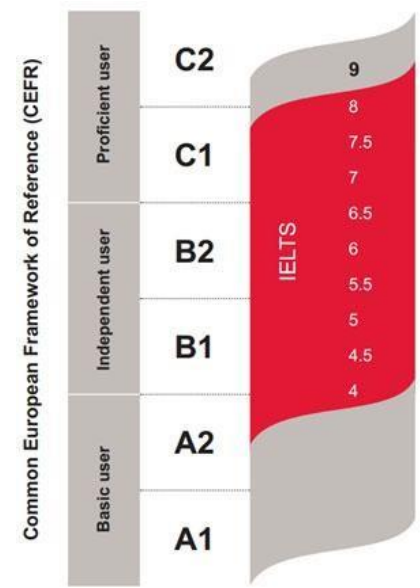

Figure 2. Equivalence of IELTS to the CEFR (IELTS, 2021)

\section{TOEFL $i B T$}

As for the TOEFL iBT, it is an official English test that is taken online at authorized centers around the world. This certification is one of the most popular and has the recognition and acceptance in more than 11,500 universities around the world and in more than 160 countries. The maximum score in the TOEFL iBT is 120 points, since this test is evaluated on a scale 
from 0 to 120 and these scores are valid for 2 years. The test is divided into four sections as shown in Table 5.

Table 5. TOEFL iBT Sections (ETS TOEFL, 2021)

\begin{tabular}{|c|c|c|c|}
\hline Sections & $\begin{array}{l}\text { Number of } \\
\text { questions }\end{array}$ & Duration & Rating \\
\hline $\begin{array}{c}\text { Reading } \\
\text { (Reading comprehension) }\end{array}$ & 30 to 40 questions & From 54 to 72 minutes & $\begin{array}{l}\text { From } 0 \text { to } 30 \\
\text { points }\end{array}$ \\
\hline $\begin{array}{l}\text { Listening (Listening } \\
\text { comprehension) }\end{array}$ & $\begin{array}{l}\text { From } 28 \text { to } 39 \\
\text { questions }\end{array}$ & From 41 to 57 minutes & $\begin{array}{l}\text { From } 0 \text { to } 30 \\
\text { points }\end{array}$ \\
\hline $\begin{array}{c}\text { Writing } \\
\text { (Written Expression) }\end{array}$ & 2 tasks & 50 minutes & $\begin{array}{l}\text { From } 0 \text { to } 30 \\
\text { points }\end{array}$ \\
\hline $\begin{array}{c}\text { Speaking } \\
\text { (Oral expression) }\end{array}$ & 4 tasks & 17 minutes & $\begin{array}{l}\text { From } 0 \text { to } 30 \\
\text { points }\end{array}$ \\
\hline
\end{tabular}

It is important to mention that the CEFR comprises three levels (A, B and C) organized into two sub-levels each; however, the TOEFL iBT certification covers only levels B1-C2. Therefore, level A is not applicable. Therefore, Table 6 shows the equivalences between the TOEFL iBT score and the CEFR.

Table 6. TOEFL iBT and CEFR Equivalences (ETS TOEFL, 2021)

\begin{tabular}{|c|c|c|c|c|c|}
\hline $\begin{array}{c}\text { CEFR } \\
\text { level }\end{array}$ & $\begin{array}{c}\text { Reading } \\
(\mathbf{0 - 3 0 )}\end{array}$ & $\begin{array}{c}\text { Listening }(\mathbf{0}- \\
\mathbf{3 0})\end{array}$ & $\begin{array}{c}\text { Speaking }(\mathbf{0}- \\
\mathbf{3 0})\end{array}$ & $\begin{array}{c}\text { Writing } \\
(\mathbf{0 - 3 0})\end{array}$ & $\begin{array}{c}\text { Overall } \\
\text { Rating } \\
(\mathbf{0 - 1 2 0})\end{array}$ \\
\hline $\begin{array}{c}\text { C1 or } \\
\text { higher }\end{array}$ & 24 & 22 & 25 & 24 & 95 \\
\hline B2 & 18 & 17 & 20 & 17 & 72 \\
\hline B1 & 4 & 9 & 16 & 13 & 42 \\
\hline A2 & n/a & n/a & 10 & 7 & n/a \\
\hline A1 & n/a & n/a & n/a & n/a & n/a \\
\hline
\end{tabular}

It should be noted that the figures indicated correspond to the minimum score that must be achieved to reach one level or another.

\section{INTERNATIONAL CERTIFICATE (FORMERLY PTE GENERAL) PEARSON}

The official International Certificate exam allows to certify the level of real English from A1 to $\mathrm{C} 2$; in addition, it evaluates the four skills in an integrated way: Listening, Reading, Speaking and Writing. (Pearson, 2021|) . In terms of its structure, the test is designed to reflect the real language that students will encounter in English-speaking environments and focuses 
on communicative ability, allowing students to show how competent they are at putting the language into practice.

In order to provide a specific grade, the test offers six proficiency levels (A1, 1, 2, 2, 3, 4, and 5) designed to assess and accredit a student's English language proficiency. Level 1 is equivalent to $\mathrm{A} 2$ on the CEFR.

It is important to note that this test is aimed at a beginner level of English, sufficient to survive in social, travel and everyday situations. Consequently, students are expected to understand very short and simple information and to express themselves simply and briefly in both speaking and writing.

\section{OXFORD TEST OF ENGLISH}

It is a test that is $100 \%$ online and has a high prestige in addition to being aligned with CEFR standards and worldwide since it is accredited by the University of Oxford (Oxford University, 2020). This test evaluates three different levels according to CEFR: B2, B1 and A2, which cover skills such as: Speaking, Listening, Reading and Writing. Candidates can choose to be assessed in just one of the skill areas or in all four.

Particularly for A2 level, the texts and assignments are designed to ensure that students, in line with the CEFR A2 descriptors, can understand and extract essential information from the audio texts which are cooperatively reviewed for maximum comprehension ability.

The exam takes approximately 2 hours to complete, divided as follows: 15 minutes for Speaking, 30 minutes for Listening, 35 minutes for Reading and finally 45 minutes for the

Writing test. Candidates who choose to take all four skills assessments are awarded an overall score of 140, comprising the average scores obtained in each skill area. The scores can be aligned to the "Below A2", "A2", "B1" and "B2" levels in the CEFR.

Now, for international equivalencies the Oxford test of English scale is 51-140, furthermore, the scale is aligned to CEFR levels B2, B1 and A2. Finally, the A2 level is equivalent to a score of 66 on the Oxford test.

\section{CENNI (National Language Level Certification)}

CENNI is a Mexican certification designed by the Mexican Ministry of Education and measures proficiency in 20 levels of English, ranging from basic to expert. In addition, it is supported by more than 40 nationally and internationally recognized evaluation instruments such as Cambridge, TOEFL, ALTE among others. The documents that can be obtained by taking this test are: Constancy (of less academic rigor), Certification (of greater academic rigor) and Diploma (only for the most advanced levels) (Secretaría de Educación Pública, 2021). This certification is valid for five years and is used by public schools. CENNI is the national certification for English teachers.

\section{CONCLUSIONS}

After the analysis of the different tools that exist today for the validation of English speaking around the world, they clearly denote a list of skills necessary to justify the equivalence to an A2 level according to the CEFR. In this sense, in the first instance it is understood that this scale refers to a person with still limited abilities within the communication in this language; however, it refers to a survival level that, although not yet with fluent competence, can engage in conversations within the main areas of everyday life. 
Now, having clear the parameters that would be reached, defined methodologies for the calculation of this level are characterized; where it is observed that, in all the existing tests it points towards two types of tests. The first, based on an approximation of the grammatical load, with the help of different activities such as comprehension texts and open questions to quantify the knowledge of verb tenses, vocabulary and structure of written and reading expression; and a second type of test with a qualitative approach that allows to identify the ease of expression and eloquence in conversations that this level is responsible for.

It should be noted that universities, NGOs, government agencies and companies are the organizations that most often request English certifications. In many occasions, having a certification is the difference between entering an English-speaking university or not, and the same happens to be hired in a company. Therefore, certifications represent an obvious competitive advantage and are the key, in many cases, for entry into academic studies or for jobs labeled as desirable; therefore, it is not only important to have any English certification, but to have the right one. Due to the interest of the researchers, considering that it is appreciated that in a group of universities and schools the A2 level of proficiency is a requirement for entrance or degree, the analysis of this work focused on characterizing the A2 level, showing the skills required to be accredited or certified, as well as presenting various certification options, which provides a theoretical perspective of the level and makes known its physiognomy, as well as the capabilities, skills and possibilities of a person who demonstrates this skill, which provides a basis for future decisions or projects.

\section{BIBLIOGRAPHY}

Becerril, I. (2015). En México sólo 5\% de la población habla inglés: IMCO. El Financiero. Obtenido de El Financiero: https://www.elfinanciero.com.mx/economia/enmexico-solo-de-la-poblacion-habla-ingles-imco/

British Council (2021). Niveles de inglés. British Council. Obtenido de British Council: https://www.britishcouncil.es/ingles/niveles.

Cambridge English. (2021). Certificaciones y pruebas para cada alumno. Cambridge University Press \& Assessment 2021. Obtenido de https://www.cambridgeenglish.org/latinamerica/exams-and-tests/

Chávez, A. (2020). Más de tres cuartas partes de la gente en México ha perdido trabajos por no saber inglés. Merca 2.0. Obtenido de Merca 2.0: https://www.merca20.com/mas-detres-cuartas-partes-de-la-gente-en-mexico-ha-perdido-trabajos-por-no-saber-ingles/

Chávez-Zambano. (2017). La importancia del aprendizaje y conocimiento del idioma inglés en la enseñanza superior. Dominio de las Ciencias, 759-771.

CIFE (2016). Metodología del registro documental para la búsqueda y organización de la información científica (1ra. Ed.). México: CIFE, 2016.

Cambridge Assessment English (2021). A2 Key. Cambridge University Press \& Assessment. Obtenido de https://www.cambridgeenglish.org/exams-and-tests/key/

English First Set (2021). English Level A2. EF Education First. Obtenido de https://www.efset.org/cefr/a2/

Entrepeneur (2018). Solo 14\% de mexicanos tiene un nivel de inglés avanzado. Entrepeneur. Obtenido de: https://www.entrepreneur.com/article/318892 
ETS TOEIC (2021). TOEIC. Educational Testing Service. Obtenido de TOEIC: https://www.toeic.mx/

ETS TOEFL (2021). TOEFL iBT® Test Content. ETS TOEFL. Obtenido de ETS TOEFL: https://www.ets.org/toefl/test-takers/ibt/about/content

Grajales, T. (2000). Tipos de investigación. DIVULGARE Boletín Científico de La Escuela Superior de Actopan, 1(1), 4-7.

Hernández, R., Fernández, C., \& Baptista, P. (2014). Metodología de la Investigación Hernández Sampieri 6a Edición.

IELTS. (2021). How IELTS is scored. International English Language Testing System. Obtenido de IELTS: https://www.ielts.org/for-test-takers/how-ielts-is-scored

Latorre, C. F. (2016). The English Importance in the International Commerce. Empresarial, 51-57.

Oxford University (2020). Oxford Test of English. Oxford University Press. Obtenido de: https://elt.oup.com/feature/global/oxford_test_of_english/?cc=gb\&selLanguage=e n\&mode $=$ hub

Pearson (2021|). International Certificate. Pearson. Obtenido de International Certificate Pearson: https://internationalcertificate.pearsonelt.es/

Secretaría de Educación Pública (2021). Certificación Nacional de Nivel de Idioma (CENNI). Obtenido de CENNI: https://www.cenni.sep.gob.mx/ 